\section{Social Support, Age and Borderline Personality}

Journal PSIKODIMENSIA

Volume 17, No. 2, Juli - Desember 2018

ISSN cetak : 1411-6073

ISSN online : 2579-6321

DOI 10.24167/psidim.v17i2.1670

Christin Wibhowo, Sofia Retnowati; Nida Ul Hasanat

Fakultas Psikologi, Universitas Gadjah Mada

e-mail: christine.wibhowo@mail.ugm.ac.id

\begin{abstract}
This study is aimed 1).to find out relation among the social support and BP. 2).Totest the difference BP based on age. The hypothesis in this study is1). there is a relationship between social support and BP. 2). There is difference BP on based age. All data are measured with scales. The partisipans to this study amounted to 247 adults aged 20-40 years. The data obtained are analyzed with SPSS program. The result showed that 1).There is norelationship between social support and BP $(r=-0,40 ; p=0,182) 2)$.There is no difference BP on based age $(F=1,491 ; p=0,097)$.Methodological recommendations are as follows 1)pay attention to sources and types of social support 2).analyze the profile of trains in each age group and gender.
\end{abstract}

Keywords : Social Support, Age, Borderline Personality

\section{PENDAHUUAN}

Di Indonesia, jumlah yang pasti terkait dengan orang yang memiliki kriteria kepribadian ambang (KA) belum ditemukan. Hanya saja dapt diduga adanya individu-yang mengalami KA. Menurut DSM-5, seseorang dapat mengalami KA jika ia paling sedikit memiliki lima kriteria dari sembilan kriteria KA.Kriteria KA tersebut yaitumemiliki perasaan takut jika ditinggalkan, pola hubungan interpersonal yang tidak stabil, kabur dengan citra dirinya, impulsif, percobaan bunuh diri,suasana hati yang mudah, perasaan kosong yang kronis, sulit mengendalikan kemarahan dan adanya adanya stres yang berhubungan dengan pemikiran paranoid atau simtom disosiasi. Andri (2007) mengatakan bahwa akhir-akhir ini di Indonesia ditemukan banyak berita tentang individu yang melakukan beberapa kali perilaku kekerasan dan perilaku berisiko, seperti kawin-cerai, isyarat akan bunuh diri, dan mencelakai diri sendiri. Menurut Distel (2009), adanya perilaku-perilaku kekerasan, perilaku yang emosional, seing kehilangan pekerjaan, penyalahgunaan zat, dan perilaku mudah menikah-mudah cerai yang ditunjukkan oleh individu tidak bisa diabaikan karena bisa saja perilaku tersebut merupakan tanda-tanda adanya KA. Seseorang dapat didiagnosis mengalami KA jika ia sudah berusia 18 tahun.

Kernberg (dalam Nevid, 2005) menekankan bahwa hubungan individu dengan orang lain merupakan faktor penting bagi individu dalam membentuk kepribadian. Melalui hubungan tersebut, seseorang bisa merasa didukung sehingga tidak mengalami KA. Dukungan sosial meliputi tersedianya bantuan psikologis 
dan material yang dapat diperoleh seseorang dalam jaringan sosial (Eidelman, 2011). Dukungan sosial yang diberikan secara nyata memang sangat berperan terhadap kesehatan psikologis. Walaupun demikian, perasaan mendapat dukungan sosial jauh lebih berdampak terhadap kesehatan individu (Cohen \& William dalam Eidelman, 2011).. Hal ini juga disampaikan oleh Thomas (2015). Menurut Thomas, dukungan sosial adalah suatu hubungan yang bisa membuat individu masuk dalam jaringan sosial, dan dapat saling berinteraksi serta saling berbagi dengan individu lain. Hubungan tersebut mampu melindungi individu dari perilaku berisiko, seperti bunuh diri.

Eidelman (2011) dan Harrison et al.(2010) meneliti hubungan dukungan sosial dan emosi yang labil. Skala dukungan sosial yang digunakan mencakup aspek bantuan langsung (materi dan adanya kehadiran orang yang dapat diajak berdiskusi saat menemukan persoalan), harga diri (perasaan dicintai, berharga, dan mampu), dan rasa memiliki (adanya kehadiran orang lain yang membuatnya nyaman dalam berinteraksi sosial). Nilai yang dihasilkan dari pengisian skala tersebut menunjukkan persepsi individu terhadap dukungan sosial yang diperoleh.

Kaswlow et al. (Thomas, 2015) melakukan penelitian dengan partisipan di Afrika. Hasil penelitiannya menunjukkan bahwa perilaku bunuh diri (salah satu kriteria KA) seringkali disebabkan oleh tekanan akibat kondisi finansial yang rendah. Dengan demikian, jika seorang individu mendapat dukungan sosial (yang juga meliputi bantuan langsung atau material) maka individu tersebut akan merasa nyaman dan tidak melakukan bunuh diri. Mirip dengan penelitian tersebut, Barros (2016) meneliti tentang peran dukungan sosial terhadap KA. Hasil penelitiannya menunjukkan bahwa individu yang tidak memiliki perasaan mendapat dukungan sosial akan memiliki kriteria KA lebih banyak dibanding individu yang merasa memiliki dukungan sosial. Kesimpulan ini sesuai dengan hasil temuan dari Crowell et al. (2009) dan Sajadi et al. (2015), yang menyatakan bahwa faktor sosial-ekonomi merupakan salah satu faktor dari terjadinya KA.

Perasaan mendapat dukungan sosial dapat mempercepat pemulihan bagi individu yang memiliki emosi tidak stabil, seperti dalam kriteria KA (Eidelman, 2011). Seorang yang mendapat dukungan sosial akan merasa tidak sendirian, nyaman karena mendapat dukungan, dan tenang karena mendapat perhatian, sehingga ia tidak mengalami gangguan tidur. Menurut Eidelman, seorang individu yang dapat tidur dengan baik akan memiliki hubungan interpersonal yang baik juga.

Penelitian yang dilakukan oleh Kathleen (2016) juga menghasilkan kesimpulan bahwa ada hubungan negatif antara dukungan sosial yang dirasakan oleh individu dengan kriteria KA. Semakin seorang individu merasa mendapat dukungan sosial maka ia semakin tidak memiliki kriteria dalam KA.

Menurut Saleem et al.(2013), dukungan sosial berkorelasi negatif dengan rasa marah yang selanjutnya akan membuat seseorang lebih memilih berperilaku sehat (tidak kecanduan alkohol). Seorang individu yang merasa ditolak oleh lingkungan sosial dan merasa tidak didukung akan melarikan diri kepada perilaku berisiko.

Sejalan dengan temuan penelitianpenelitian tersebut, Elzy (2011) juga menyimpulkan hasil penelitian yang sama. 
Dalam penelitiannya,ia menggunakan partisipan sebanyak 290 wanita. Hasil penelitiannya menunjukkan bahwa dukungan sosial yang rendah akan meningkatkan kriteria KA.

Penelitian-penelitian yang telah dilakukan menguji hubungan dukungan sosial terhadap beberapa kriteria dari KA dan belum ada penelitian yang menguji hubungan dukungan sosial dan semua kriteria dalam KA. Hal ini juga yang diduga membuat nilai korelasi antara dukungan sosial dan KA tidak terlalu besar (berkiasar antara 0,18 - 0,3). Oleh karena itu, perlu dilakukan penelitian tentang peran dukungan sosial terhadap KA.

Selain dukungan sosial, usia juga didugaberhubungan dengan KA. Peran usia terhadap gangguan kepribadian mirip dengan peran budaya. Ada stereotip dari masyarakat terhadap golongan usia tertentu yang membuat individu berperilaku sesuai tuntutan tersebut (Chan et al., 2012). Dalam penelitian lintas budaya yang dilakukan oleh Chan terhadap 3.323 partisipan, ditemukan bahwa orang-orang dalam kelompok usia 30 tahun ke atas diharapkanmemiliki emosi stabil, tidak impulsif, tidak memberontak, dan bijak dalam memilih jalan keluar dari persoalan. Sedangkan individu dengan kelompok usia di bawah 30 tahun, akan dipandang sebagi individu yang impulsif, suka menentang, namun lebih terbuka pada perubahan. Dengan demikian, maka diduga individu pada kelompok usia 30 tahun ke atas akan lebih terhindar dari gangguan kepribadian karena mereka berusaha menyesuaikan diri dengan pandangan atau tuntutan masyarakat tersebut.

Penelitian dari Shea et al. (2009) menggunakan 216 partisipan yang mengalami KA dan telah mengikuti terapi untuk menurunkan kriteria KA yang dimiliki. Partisipan dibagi menjadi dua, yaitu kelompok usia muda (di bawah 30 tahun) dan usia tua (30-60 tahun). Hasil penelitian tersebut ialah bahwa kriteria KA pada kelompok tua lebih cepat menurun dibanding pada partisipan dengan kelompok muda. Akan tetapi setelah 6 tahun, hasil penurunan kriteria KA antara kelompok usia muda dan tua tidak berbeda.

Dengan menggunakan dua kelompok partisipan, yaitu kelompok tua (40-60 tahun) dan kelompok muda (20-40 tahun), Coolidge et al. (2000) menyimpulkan bahwa kriteria KA lebih banyak ditemukan pada kelompok usia muda dibanding pada individu dengan kelompok usia tua. Jeramerupakan istilah yang mungkin tepat untuk menggambarkan tentang peran usia terhadap KA. Seseorang dengan KA tentu akan banyak menemui masalah akibat perilaku KA yang ditunjukkannya. Masalah yang ia hadapi, antara lain ia banyak tidak disukai orang lain karena kemampuannya dalam berhubungan interpersonal tidak baik. Ia juga belajar bahwa perilaku berisiko yang ia lakukan ternyata tidak menyelesaikan persoalan.Dengan bertambahnya usia, seseorang yang mengalami KA didugasudah mampu menghindari stimulus-stimulus yang membuat kriteria KAyang dimilkinya muncul.Kemungkinan ia akan menghindari pekerjaan-pekerjaan yang melibatkannya dalam kelompok dan ia lebih memilih bekerja mandiri untuk menghindari konflik interpersonal. Perilaku berisiko juga akan ia tinggalkan karena ada rasa malu untuk melakukannya mengingat usia tak lagi muda. Biasanya kriteria KA tidak akan nampak pada individu di atas usia 40 tahun. Oleh karena ini dalam penelitian ini partisipan akan dipilih dari individu berusia 20-40 tahun. 
Penelitian-penelitian tentang hubungan dukungan sosial, usia dan kepribadian ambang baru dilakukan di negara Barat, maka penelitian tersebut penting untuk dilakukan di Indonesia karena banyak perilaku yang menujukkan kriteria KA dilakukan oleh masyarakat Indonesia. Berdasarkan hasil penelitian yang sudah dilakukan, maka dapat diambil kesimpulan sementara bahwa ada hubungan antara dukungan sosial dan KA. Sealin itu, ada perbedaan KA jika ditinjau dari usia.

\section{METODE}

Variabel dalam penelitian ini yaitu $\mathrm{KA}$, dukungan sosial dan usia yang akan diukur dengan skala. Jumlah partisipan dalam penelitian ini yaitu 247 orang yang berusia 20-40 tahun.
Pemilihan partisipan dalam penelitian ini dilakukan dengan cara mengundang kelompok calon partisipan yang sesuai dengan kriteria untuk mengikuti acara ramah-tamah. Kepada partisipan dijelaskan tentang tujuan penelitian, yaitu untuk memahami kehidupan sehari-hari partisipan.Partisipan juga mendapat penjelasan tentang cara pengisian, perkiraan waktu yang digunakan untuk mengisi skala, dan dijaminnya kerahasiaan partisipan.

Dari hasil uji konsistensi internal maka dapat diketahui bahwa aitem pada skala KA dan dukungan sosial dinyatakan sesuai. Estimasi reliablitas skala berdasar ouput SPSS, dapat dilihat pada tabel 1.

Tabel 1: Estimasi Reliabilitas

\begin{tabular}{lllll}
\hline \multicolumn{1}{c}{ Variabel } & & Cronbach's Alpha & Cut Off & Ket. \\
\hline Skala Kepribadian Ambang & 0,811 & 0,6 & Reliabel \\
Skala Dukungan Sosial & 0,708 & 0,6 & Reliabel \\
\hline
\end{tabular}

Analisis data yang digunakan adalah uji hubungan (product moment) dan ujia beda (uji-t).Selain itu juga dilakukan uji normalitas

untuk mengetahui normal tidaknya data KA antara responden laki-Laki dan perempuandan antara tiga kelompok umur (20 tahu, 30 tahu, dan 40 tahun).Pengujian normalitas dilakukan menggunakan uji Kolmogorov Smirnov. Hasil pengujian asumsi normalitas di atas diketahui bahwa probabilitas dari dataKA bernilai lebih besar dari taraf signifikansi (Alpha $=5 \%$ ). Dengan demikian, dataKA dinyatakan normal.
Sebelum melakukan pengujian $t$ independent, maka harus dilakukan pengujian homogenitas. Pengujian homogenitas data KA antara responden laki-laki dan perempuan serta uji homogenitas untuk kelompok umur. Uji homogenitas dilakukan menggunakan Levene Test. Hasil pengujian homogenitas data KA antara responden laki-laki dan perempuan dan antar kempok umur yaitu homogen.

HASIL

Berdasar hasil analisa data maka ditemukan bahwa dukungan sosialtidak berhubungan dengan KA. Hal ini dikarenakan nilai estimate sebesar -0,408 dengan probabilitas sebesar 0,182. 
Christin Wibhowo: Social Support, Age and Borderline Personality ...

Hasil pengujian perbedaan rata- pada Tabel 2. rataKA berdasar jenis kelamin disajikan

Tabel 2. Uji Beda KA Berdasar Jenis Kelamin

\begin{tabular}{cccc}
\hline KA & Rata-Rata & T-test & Probabilitas \\
\hline Laki-Laki & 18880 & $-0,280$ & 0,779 \\
Perempuan & 1.8978 & & \\
\hline
\end{tabular}

Dari hasil rata-rata diketahui bahwa responden perempuan memiliki nilai ratarata KA yang lebih tinggi dari laki-laki. Walaupun demikian berdasrakan hasil pengujian yang tertera pada Tabel 2 dapat diketahui bahwa tidak terdapat perbedaan KA yang signifikan antara responden lakilaki dan perempuan.

Selanjutnya menguji perbedaanKA berdasarkan usia. Dari hasil analisadiketahui bahwa responden dengan usia 23 tahun memiliki nilai rata-rata lebih tinggi dibandingkan dengan usia yang lain. Walaupun demikian uji $F$ yang dihasilkan sebesar 1,491 dengan probabilitas sebesar 0,097 (Tabel 3). Dengan demikian, dapat dinyatakan bahwa tidak terdapat perbedaan KA yang signifikan berdasarkan usia.

Tabel 3. Hasil Uji Beda KA Berdasar Usia

\begin{tabular}{cccc}
\hline Usia & Rata-rata & F & \\
22 & 2,03 & \\
23 & 2,04 & \\
24 & 2,01 & \\
25 & 1,83 & \\
26 & 1,77 & \\
27 & 1,86 & \\
28 & 1,92 & \\
29 & 2,01 & \\
30 & 1,99 & \\
31 & 1,83 & \\
32 & 1,86 & \\
33 & 1,97 & \\
34 & 1,88 & \\
35 & 1,79 & \\
36 & 1,78 & \\
37 & 1,86 & \\
38 & 1,90 & \\
39 & 1,79 & \\
40 & 2,01 & \\
Total & 1,89 & \\
\hline
\end{tabular}




\section{DISKUSI}

Penelitian ini menyimpulkan bahwa dukungan sosial tidak berhubungan dengan KA. Berarti temuan ini tidak sesuai dengan hasil pada penelitianpenelitian terdahulu. Hal ini dikarenakan pada penelitian-penelitian sebelumnya tidak melibatkan semua aspek dalam dukungan sosial. Demikian juga dalam kaitannya dengan KA, hanya diambil satu kriteria saja.

Eidelman (2011), menyimpulkan bahwa individu yang memiliki emosi tidak stabil (salah satu kriteria KA), biasanya ditandai dengan adanya keluhan fisik (sulit tidur) dan kesulitan dalam berinteraksi sosial. Seseorang yang mendapat dukungan emosi (salah satu aspek dalam dukungan sosial) akanmerasa tidak sendirian serta nyaman karena mendapat dukungan dan tenang karena mendapat perhatian, sehingga ia tidak mengalami gangguan tidur. Selanjutnya, individu yang dapat tidur dengan nyenyak akan memiliki emosi yang stabil.

Dalam penelitian yang dilakukan oleh Rasonabe (2013) dan Harrisonetal. (2010),ditemukan bahwa jenis dan sumber dukungan sosial merupakan hal yang berperan penting. Dukungan yang dirasakan oleh individu terutama dari lingkungan keluarga, akan menurunkan kriteria pada KA, terutama dalam merasa kosong. Hal ini sejalan dengan hasil penelitian dari Belangeret al. (2016). Hasil penelitian Belanger menyimpulkan bahwa dukungan yang dibutuhkan seseorang terkait dengan latar belakang budaya, pendidikan, dan keadaan ekonomi. Edmonds, Paul, dan Sibley (2011) berdasar penelitiannya juga menyimpulkan dukungan sosial dipengaruhi oleh jenis kelamin. Pada partisipan wanita, dukungan keluarga, seperti dukungan ibu, ipar, dan suami, lebih dibutuhkan dibanding dukungan dari teman. Dukungan dari teman berperan dalam menurunkan gangguan kepribadian hanya pada partisipan yang berusia 20 tahun.

Dalam penelitian ini, jumlahpartsipan yang terbanyak berada pada kelompok perempuan dengan usia 30-40 tahun yang menurut Wise, Smith,\& Armelie (2017) lebih membutuhkan dukungan dari keluarga. Pengukuran dukungan sosial dalam penelitian ini ialah dengan mengukur dukungan dari teman. Hal inilah yang menyebabkan tidak adanya hubungan antara dukungan sosial dan KA.

Hasil dalam penelitian juga menyimpulkan bahwatidak ada perbedaan KA pada golongan usia 20, 30, dan 40 tahun. Hasil penelitian ini berbeda dengan hasil penelitian dari dari Shea et al. (2009) dan Coolidge et al. (2000) yang menyimpulkan bahwa kriteria KA lebih banyak ditemukan pada kelompok usia muda dibanding pada individu dengan kelompok usia tua. Diduga, perbedaan hasil penelitian ini karena budaya Indonesia berbeda dengan budaya tempat penelitian sebelumnya dilakukan. Pada budaya Indonesia yang menganut paham kolektivisme yang sangat mengutamakan keharmonisan hubungan dengan orang lain. Penelitian sebelumnya dilakukan pada budaya individualisme yang mengutamakan kemandirian. Dalam budaya individualisme, menjalin hubungan interpersonal (merupakan kriteria KA) tidak menjadi prioritas dalam kehidupan orang muda. Pada usia yang lebih tua baru disadari bahwa menjalin hubungan harmonis merupakan sesuatu yang penting. Dengan demikian, dapat dipahami bahwa nilai KA akan tinggi di usia muda. Hal tersebut berbeda pada budaya kolektivisme. Jika seseorang tidak 
suka dengan orang lain, maka ia akan memendam masalahnya sendiri tanpa memperlihatkan kepada orang lain (Triandis, dalam Berry, 1999). Berapapun usia seseorang, mereka akan dituntut oleh budaya kolektivisme untuk mempertahankan keharmonisan hubungan interpersonal. Dengan demikian, pada budaya kolektivisme, nilai KA tidak berbeda berdasar golongan usia.

Hasil berikutnya dalam penelitian ini yaitu tidak ada perbedaan yang signifikan pada nilai KA berdasar jenis kelamin. Hal ini sesuai dengan hasil penelitian yang dilakukan oleh Skodol dan Bender (2003). Jika terjadi perbedaan biasanya karena beberapa kritera KA lebih terlihat pada wanita atau pria. Akan lebih baik jika dalam penelitian selanjutnya menganalisa tentang profil KA pada pria dan wanita.

\section{SIMPULAN}

Simpulan dalam penelitian ini yaitu tidak ada hubungan antara dukungan sosial dan kepribadian ambang. Hasil lainnya yaitu tidak ada perbedaan KA berdasarkan jenis kelamin dan usia.

Ada beberapa saran untuk peneliti selanjutnya yaitu:

1. Mencari data tentang jumlah individu dengan KA di Indonesia sehingga diperoleh data yang pasti.

2. memperhatikan sumber dan jenis dukungan sosial jika akan meneliti hubungannya dengan KA.

3. memperhatikan profil KA pada masing-masing golongan usia dan jenis kelamin.

\section{DAFTAR PUSTAKA}

Andri, A. K. (2007). Neurobiologi Gangguan Kepribadian Ambang: Pendekatan Biologis perilaku impulsif dan agresif. Maj Kedokt Indon, 57(4), 123-128.

Barros, K. (2016). Borderline Personality Disorder Features, perceived social support, sleep disturbance, and rejection sensitivity. Thesis. Arizona State University.

Belanger, E., Ahmed, T., Vafaei, A., Curcio, C. L., \& Phillips, S. P. (2016). Sources of social support associated with health and quality of life: a cross-sectional study among Canadian and Latin American older adults. BPMJ Open. 660. E011503.

Chan, W., McCrae, R. R., Fruyt, F. D., Lee, J., Lockenhoff, C. E., \&DeBolle, M. (2012). Stereotypes of age differences in personality traits: Universal and Accurate?.J Pers Soc Psychol, 103(6), 10501066. DOI: $10.1037 / \mathrm{a} 0029712$.

Coolidge, F. L., Segal, D. L., Hook, J. N., \& Stewart, S. (2000). Personality disorder and coping among anxious older adults. Journal of anxiety disorders, 14(2), 157-172.

Distel, M. (2009). Indivdual Differences in Borderline Personality Traits: A Genetic Perspective. Amsterdam: Drukkerij Van Werkhoven.

Edmonds, J. K., Pail, M. \& Sibley, L. M. (2011). Type, content, and sources of social support perceived by woman during pregnancy: evidence from Matlab, Bangladesh. Journal of Health, Population and Nutrition. Apr; 29(2):163-173. 
Christin Wibhowo: Social Support, Age and Borderline Personality ...

Eidelman, P. (2011). Social support and social strain in Iiter-episode Bipolar Disorder. Disertasi. Berkeley: University of California.

Elzy, M.B. (2011). Examining the relationship between childhood sexual abuse and borderline personalty disorder : does social support matter?. Journal of Child Sexual Abuse. (20); 284-304.

Harrison, K. E., Dombrovski, A.Y., Morse, J.Q., Houck,P., Schlernitzauer, M., Reynold, C.F., Szanto, K. (2010). Alone? Perceived social support and chronic interpersonal difficulties in suicidal elders. International Journal of Psychogeriatry, 22(3), 445-454.

DOI: 10.1017/S1041610209991463.

Kathleen, B. (2016). Borderline Personalityfeatures,perceive social support, sleep disturbance, and rejection sensitivity. Disertasi. Arizona State University Nevid, J.S., Rathus, S.A., \& Greene, B. (2005). Abnormal psychology in a changing world.Fifth Edition. (Psikologi Abnormal) (Edisi Ke Lima). (Tim Fakultas Psikologi Indonesia, terj.). Jakarta: Penerbit Erlangga

Rasonabe, M.B. (2013). Predisposed Borderline Personality Disorder (prebpd). ISS dan MLB, 998-1009.

Sajadi, S. F., Zargar, Y., Honarmand, M.M., \& Arshadi, N. (2015). Designing and testing a model of some presedents and outcomes of Borderline Personality Disorder in High School students of Shiraz. InternationalJournal School Health, 2(3), 1-8.
Saleem, M., Tahir, M.A., \& Huda N.U. (2013). Perceived social support and clinical anger among drug addicts of Southern Punjab, Pakistan. Pakistan Journal of Commerce and Social Sciences, 7(2), 298-308.

Shea, M.T., Edelen, M. O., Pinto, A., Yen, S., \& Gunderson, J. G. (2009). Improvement in Borderline Personality Disorderin relationship to age. Acta Psychiatr Scand, 119(2), 143-148. DOI:10.1111/j.16000447.2008.01274.x.

Thomas, A.L. (2015). Suicidal thoughts and behavior among black College Students: Examining the impact of distress tolerance and social support on suicidality. Master Thesis dan specialist Projects. Kentucky: Western Kentucky University.

Wise, A. E., Smith, B. C.,\& Armelie, A. P. (2017). Age moderates the relationship between source of social support and mental health in racial minoriting: lesbian, gay and bisexual youth. Journal of Health Psychology. First Published. 